\title{
THE IMPLEMENTATION OF THE 21TH CENTURY COMPETENCY FOR ELEMENTARY SCHOOL TEACHERS AT CURRICULUM 2013 TRAINING CENTRAL JAVA PROVINCE YEAR 2017
}

\section{Mulida Hadrina Harjanti}

LPMP Jawa Tengah

mulidaharjanti@gmail.com

\section{Article History}

accepted 09/07/2018

approved 01/08/2018

published 17/09/2018

\section{Keywords}

2013 curriculum, 21st century competence, character education

\begin{abstract}
The purpose of writing this paper is; 1) to understand methods and strategies in applying 21st century competency $(4 \mathrm{C}=$ critical thinking, creative thinking, communication, and collaborative) and;2) to show the results of the competence of 21 st century elementary school teachers in training curriculum 2013. The method used in this research is descriptive qualitative method. The results and discussion of this paper is the strategy of training in the application of 21st century competence and Strengthening Character Education. first teacher show and give exemplary to the character and competence of the 21st century. The role of teachers as examples must be highlighted. If you want to teach the character, then the teacher must first display their character. While the results of the application of 21st century competence and Strengthening Character Education after the 2013 curriculum training can be shown by increasing the achievement of the quality report cards on the competency standards of graduates, content, process, and assessment standards.
\end{abstract}

Social, Humanities, and Education Studies (SHEs): Conference Series https://jurnal.uns.ac.id/shes

p-ISSN 2620-9284

e-ISSN 2620-9292 


\section{PENDAHULUAN}

Tantangan masa depan generasi bangsa Indonesia tidak semakin sederhana, tetapi semakin kompleks. Tidak hanya tantangan perubahan peradaban dunia, akan tetapi tantangan penyiapan generasi yang berkualitas. Bagaimana cara menyiapkan generasi bangsa yang berkualitas yaitu generasi yang bisa menghadapi perubahan peradaban dunia? Salah satu yang bisa menjawab tantangan tersebut adalah melalui bidang pendidikan. Pendidikan seperti apa yang akan menyiapkan generasi yang akan datang yang penuh tantangan tersebut. Hal tersebut dapat terjawab salah satunya dengan menyiapkan kurikulum baru.

Kurikulum seperti apa yang bisa menyiapkan generasi masa depan penuh tantangan tersebut. Kurikulum yang bisa memperkuat kompetensi (pengetahuan, keterampilan, dan sikap) dan bisa menumbuhkan kecintaan dan kebanggaan generasi bangsa yang bangga menjadi bangsa Indonesia. Generasi yang memiliki kompetensi sesuai tuntutan abad kekinian, berkarakter kuat, mampu dan menyadari bahwa mereka sebagai makhluk dan hamba Tuhan Yang Maha Esa, memiliki wawasan keilmuan bagus, serta cinta tanah air.

Dengan kesadaran tersebut, maka akan menumbuhkan nilai transendental dan nilai keagamaan yang kuat, sehingga akan dapat menumbuhkan sifat kasih sayang, toleran, saling menghargai, saling menghormati, dapat menjauhkan diri dari perilaku distruktif dan anarkis, serta kompetensi yang dapat bersaing dengan bangsa lain di dunia. Kesadaran sebagai makhluk Tuhan YME juga akan menumbuhkan sifat jujur, karena merasa selalu ada yang mengawasi dalam setiap aktivitasnya. Alangkah indahnya bila sesama makhluk dan hamba termasuk lingkungan alam semesta tumbuh rasa kasih sayang secara tulus dan jujur.

Proses penanaman pendidikan kompetensi abad 21 dan karakter tersebut telah berjalan seiring dengan diberlakukannnya kurikulum 2013 mulai tahun 2013 hingga saat ini. Hasil kompetensi abad 21 dan pendidikan karakter yang telah diintegrasikan ke dalam pelatihan kurikulum 2013 bagi guru SD dapat dilihat dari rapor mutu satuan pendidikan. Rapor mutu satuan pendidikan yang dihasilkan dari program pemetaan Dirjen Pendidikan Dasar dan Menengah Tahun 2017 provinsi Jawa Tengah. Hasil pemetaan tersebut dapat dilihat pada gambar di bawah ini.

Tabel. 1 Capaian SNP Standar SKL, Isi, Proses, dan Penilaian

\begin{tabular}{|c|l|c|c|c|c|}
\hline NO & \multicolumn{1}{|c|}{ STANDAR/INDIKATOR } & SD & SMP & SMA & SMK \\
\hline $\mathbf{1}$ & Standar Kompetensi Lulusan & $\mathbf{5 , 9 9}$ & $\mathbf{5 , 6 7}$ & $\mathbf{5 , 7}$ & $\mathbf{5 , 4 7}$ \\
\hline 1.1. & Lulusan memiliki kompetensi pada dimensi sikap & 6,84 & 6,8 & 6,85 & 6,81 \\
\hline 1.2. & $\begin{array}{l}\text { Lulusan memiliki kompetensi pada dimensi } \\
\text { pengetahuan }\end{array}$ & 3,79 & 2,84 & 2,94 & 2,7 \\
\hline 1.3. & $\begin{array}{l}\text { Lulusan memiliki kompetensi pada dimensi } \\
\text { keterampilan }\end{array}$ & 6,33 & 6,43 & 6,61 & 6,56 \\
\hline $\mathbf{2}$ & Standar Isi & $\mathbf{5 , 5 4}$ & $\mathbf{5 3 2}$ & $\mathbf{5 , 1 4}$ & $\mathbf{5 , 0 7}$ \\
\hline 2.1. & $\begin{array}{l}\text { Perangkat pembelajaran sesuai rumusan kompetensi } \\
\text { lulusan }\end{array}$ & 5,72 & 4,94 & 4,9 & 5,01 \\
\hline 2.2. & $\begin{array}{l}\text { Kurikulum Tingkat Satuan Pendidikan dikembangkan } \\
\text { sesuai prosedur }\end{array}$ & 5,58 & 5,55 & 5,74 & 5,82 \\
\hline 2.3. & Sekolah melaksanakan kurikulum sesuai ketentuan & 5,43 & 5,87 & 5,33 & 5,23 \\
\hline $\mathbf{3}$ & Standar Proses & $\mathbf{6 , 4 1}$ & $\mathbf{6 , 1 4}$ & $\mathbf{6 , 1 3}$ & $\mathbf{5 , 9 2}$ \\
\hline 3.1. & $\begin{array}{l}\text { Sekolah merencanakan proses pembelajaran sesuai } \\
\text { ketentuan }\end{array}$ & 6,62 & 6,48 & 6,52 & 6,48 \\
\hline 3.2. & Proses pembelajaran dilaksanakan dengan tepat & 6,57 & 6,36 & 6,32 & 6,15 \\
\hline 3.3. & $\begin{array}{l}\text { Pengawasan dan penilaian otentik dilakukan dalam } \\
\text { proses pembelajaran }\end{array}$ & 6,15 & 6,04 & 6,21 & 6,12 \\
\hline
\end{tabular}




\begin{tabular}{|c|l|l|l|l|l|}
\hline $\mathbf{4}$ & Standar Penilaian Pendidikan & $\mathbf{5 , 8 6}$ & $\mathbf{5 , 7 7}$ & $\mathbf{5 , 9 3}$ & $\mathbf{5 , 7 6}$ \\
\hline 4.1. & Aspek penilaian sesuai ranah kompetensi & 6,32 & 6,42 & 6,56 & 6,37 \\
\hline 4.2. & Teknik penilaian obyektif dan akuntabel & 5,61 & 5,54 & 5,72 & 5,6 \\
\hline 4.3. & Penilaian pendidikan ditindaklanjuti & 6,3 & 6,16 & 6,24 & 6,1 \\
\hline 4.4. & Instrumen penilaian menyesuaikan aspek & 5,45 & 5,36 & 5,62 & 5,47 \\
\hline 4.5. & Penilaian dilakukan mengikuti prosedur & 5,65 & 5,39 & 5,52 & 5,26 \\
\hline
\end{tabular}

http://pmp.dikdasmen.kemdikbud.go.id/raporNG/index.php (Februari 2018)

Khusus untuk data jenjang Sekolah Dasar (SD) dapat dicermati pada standar kompetensi lulusan (SKL) yang terdiri dari 3 aspek yaitu, sikap, pengetahuan, dan keterampilan. Jika hasil yang diharapkan pada setiap standar adalah 7,00, maka pada standar SKL masih belum tercapai, yaitu masih 5,99. Dari ketiga aspek tersebut, aspek sikap skornya 6,84, sehingga masih perlu ditingkatkan lagi menjadi 7,00.

Untuk menciptakan harapan peningkatan pada aspek sikap tersebut perlu metodologi, strategi, dan materi pembelajaran yang merangsang tumbuhnya kepenasaran intelektual dengan lebih menonjolkan melalui membangun pola pikir, tradisi, dan budaya keilmuan, menumbuhkan kreativitas dan sekaligus daya inovasi melalui jiwa kurikulum 2013 didukung program pembiasaan, dan proses pembelajaran langsung dan tidak langsung.

Permasalahan yang dapat diangkat pada makalah ini adalah: 1) bagaimana metode dan strategi dalam penerapan kompetensi abad 21 dan Penguatan Pendidikan Karakter (PPK) pada pelatihan kurikulum 2013; 2) bagaimana hasil penerapan kompetensi abad 21 dan PPK pada pelatihan kurikulum 2013.

\section{METODE}

Penelitian dalam makalah ini menggunakan pendekatan kualitatif deskriptif. Data-data yang digunakan pada penelitian ini dimaksudkan untuk memperoleh informasi dalam penyelesaian rumusan masalah. Data-data yang digunakan dalam penelitian ini diantaranya adalah: 1) Rapor mutu Pemetaan Mutu Pendidikan (PMP) jenjang SD Provinsi Jawa Tengah Tahun 2017; dan 2) Dokumen pelatihankurikulum 2013. Sedangkan pengambilan data melalui teknik observasi dan studi dokumentasi.

\section{HASIL DAN PEMBAHASAN \\ 1. Metode dan Strategi Penerapan kompetensi Abad 21 dan Penguatan Pendidikan Karakter (PPK) pada Pelatihan Kurikulum 2013 \\ a. Konsep Kurikulum 2013}

Kurikulum 2013 telah diterapkan sejak tahun 2014, 2015, 2016 secara berturut-turut di 6,25\%, 18,75\%, dan 25\% untuk Sekolah Dasar (SD) di seluruh Indonesia. Dengan demikian sampai dengan tahun 2016, Kurikulum 2013 telah dilaksanakan di 37.034 SD. Pada tahun pelajaran 2017/2018 ditargetkan pelaksanaan Kurikulum 2013 di 35\% sekolah dasar sasaran baru atau sebanyak 52.572 sekolah, sehingga diharapkan sebanyak $60 \%$ dari seluruh sekolah dasar telah menerapkan Kurikulum 2013.

Dalam Undang-Undang Nomor 20 Tahun 2003, tentang sistem Pendidikan Nasional (UU Sisdiknas) telah dirumuskan indikator strategis yaitu mengembangkan kemampuan dan membentuk watak serta peradaban bangsa yang bermartabat dalam rangka mencerdaskan kehidupan bangsa, bertujuan untuk mengembangkan potensi peserta didik agar menjadi manusia 
yang beriman dan bertakwa kepada Tuhan Yang Maha Esa, berakhlak mulia, sehat, berilmu, cakap, kreatif, mandiri, dan menjadi warga negara yang demokratis serta bertanggung jawab. Dalam memenuhi kebutuhan kompetensi abad ke-21, UU Sisdiknas juga memberikan arahan yang jelas bahwa tujuan pendidikan harus dicapai salah satunya melalui penerapan kuriulum berbasis kompetensi. Kompetensi yang mencangkup tiga aspek, yaitu sikap, pengetahuan, dan ketrampilan, sehingga menghasilkan manusia Indonesia seutuhnya(Undang-Undang Sistem Pendidikan Nasional nomor 20 Tahun 2003).

Kurikulum 2013 menuntut keseimbangan aspek sikap, pengetahuan, dan ketrampilan. Aspek sikap, pengetahuan, dan ketrampilan yang akan dicapai pada setiap jenjang itulah yang disebut sebagai Standar Kompetensi Lulusan (SKL). Standar kompetensi lulusan diturunkan menjadi 4 (empat) Kompetensi Inti (KI). Kompentensi Inti terdiri dari, Sikap ada di KI-1 (sikap kepada Tuhan YME) dan KI-2 (Sikap sosial), pengetahuan KI-3, dan Ketrampilan KI-4.

Proses pembelajaran yang terjadi dikelas harus mengacu pada cara berpikir ilmiah, yaitu melalui tahap mengamati, menanya, menalar, mencoba, dan mengkomunikasikan. Sehingga proses pembelajaran berpusat hanya pada siswa. Selain itu juga bisa menggunakan strategi discovery learning, problem base learning, dan project base learning. Harapan menggunakan menggunakan pendekatan saintifik adalah hasil akhirnya adalah siswa menjadi kreatif dan inovatif tidak hanya sekedar menghafal pengetahuan.

Selain dengan cara saintifik penilaian juga menggunakan nuansa kurikulum 2013, yaitu penilaian autentik. Penilaian autentik adalah penilaian asli dari siswa, artinya penilaian yang dilakukan selama proses pembelajaran. Penilaian yang tidak semata-mata menilai dari hasil akhir, tetapi justru prosesnya yang penting. Penilaian autentik juga tidak mengenal jawaban tunggal. Berbasis portopolio dan produk.

\section{b. Karakteristik Kurikulum 2013}

Kurikulum 2013 dikembangkan dengan karakteristik sebagai berikut:

1. Mengembangkan sikap spiritual dan sosial, rasa ingin tahu, kreatifitas, kerjasama dengan kemampuan intelektual dan psikomotorik secara seimbang,

2. Memberikan pengalaman belajar tereancana ketika peserta didik menerapkan apa yang dipelajar di sekolah ke masyarakat dan memanfaatkan masyarakat sebagai sumber belajar secara seimbang.

3. Mengembangkan sikap, pengetahuan, dan ketrampilan serta menerapkan dalam berbagai situasi di sekolah dan masyarakat.

4. Memberi waktu yang cukup leluasa untuk mengembangkan berbagai sikap, pengetahuan, dan ketrampilan.

5. Kompetensi dinyatakan dalam bentuk kompetensi inti kelas yang di rinci lebih lanjut dalam kompetensi dasar mata pelajaran

6. Kompetensi inti kelas menjadi unsur yang menyatukan kompetensi dasar, dimana semua kompetensi dan proses pembelajaran dikembangkan untuk mencapai kompetensi yang dinyatakan dalam kompetensi inti.

7. Kompetensi dasar dikembangkan berdasarkan pada prinsip saling memperkuat dan memperkaya antar mata pelajaran dan jenjang pendidikan. 


\section{c. Penguatan Pendidikan Karakter (PPK)}

Kurikulum 2013 sebagaimana dimaksud di atas berorientasi pada penguatan karakter siswa yang telah diperkuat oleh Peraturan Presiden Nomor 87 Tahun 2017 tentang Penguatan Pendidikan Karakter (Peraturan Presiden nomor 87 Tahun 2017). Melalui PPK diharapkan peserta mampu menerapkan 5 nilai karakter PPK pada proses pembelajaran di kelas, baik pembelajaran langsung maupun tidak langsung dan menyesuaikan berbagai karakteristik siswa di kelas. Manfaat dan implikasi Gerakan PPK bagi semua karakteristik siswa, pertama adalah penguatan karakter peserta didik dalam mempersiapkan daya saing siswa dengan kompetensi abad 21 (4C), yaitu berpikir kritis (critical thinking), kreativititas (creative thinking), komunikasi (communication), dan kolaborasi (collaborative).

Sedangkan dalam5 (lima) nilai-nilai utama PPK, yaitu nilai karakter 1) religius; 2) nasionalis; 3) mandiri; 4) gotong royong (sub nilai gotongroyong: antara lain menghargai, kerjasama, inklusif, komitmen atas keputusan bersama, musyawarah mufakat, tolong menolong, solidaritas, empati, anti diskriminasi, anti kekerasan, sikapkerelawanan); dan 5) nilai karakter integritas. Implementasi PPK mestinya tidak hanya sekedar menjadi tanggung jawab guru, tetapi perlu pelibatan dari berbagai pihak antara lain: 1) orang tua; 2) komite sekolah; 3) dunia usaha; 4) Akademisi/Pegiat pendidikan (partisipasi advokasi $A B K / k e l o m p o k$ marginal literasi, program inovasi); 5) pelaku seni dan budaya; dan 6) pemerintah/pemda.

Pada pelatihan kurikulum 2013 peserta (guru SD) diajak untuk memahami metode dan strategi dalam penerapan Penguatan Pendidikan Karakter (PPK) dan menunjukkan pentingnya peran karakter guru dalam implementasi kurikulum 2013. Jika ingin mengajarkan karakter, maka perlu harus menampilkan karakter guru terlebih dahulu. Peran kurikulum 2013 dalam pembentukan karakter diantaranya adalah: 1) adanya upaya keteladanan guru dan program pembiasaan karakter-karakter positif; 2) Adanya proses pendidikan karakter di sekolah, yaitu melalui peningkatan kompetensi yang utuh antara pengetahuan, keterampilan, dan sikap; 3) Pendidikan karakter pada kurikulum 2013 perlu melibatkan lingkungan, perlunya sekolah bekerjasama dengan keluarga siswa, media massa, dan lembaga-lembaga sosial lainnya untuk sama-sama berperan membendung arus karakter negatif dan membangun karakter positif bagi calon generasi bangsa.

\section{d. Strategi Penguatan Pendidikan Karakter}

Seperti halnya pada penelitian sebelumnya yang meneliti integrasi karakter pada pengelolaan kurikulum, hasilnya adalah pelaksanaan/ implementasi kurikulum pendidikan karakter di FPIPSKR belum bisa dilakukan secara maksimal karena adanya kendala-kendala, belum ada panduan, belum tercipta keteladanan pelatih/guru, sarana prasarana, dan belum ada reward and punishment (Haryati, 2017).

\section{1) Keteladanan dan Pembiasaan}

Sebenarnya proses penanaman kebaikan itu tidak bisa dijejalkan dari luar. Anak-anak butuh cermin yang bisa memantulkan kilau kebaikan dalam diri mereka. Mereka butuh upaya dan stimulasi kreatif dari kita untuk mencuatkan fitrah kebaikan itu.

Pembiasaan (habituation), adalah proses menanamkan kebiasaan tentang yang baik sehingga guru dan peserta didik memahami, mampu merasakan, dan mau melakukan yang baik. Guru berupaya 
menanamkan kebaikan di benak anak didik seperti mengukir cita rasa kebaikan di sanubari mereka, sehingga perilaku baik terpahatkan menjadi kebiasaan.

Pembentukan karakter sangat efektif pada usia-usia formatif atau disebut usia emas, karena pada usia itu terbukti sangat menentukan kemampuan anak dalam mengembangkan potensinya. Sehingga sudah selayaknya pendidikan karakter dimulai dari dalam keluarga, yang merupakan lingkungan pertama bagi pertumbuhan karakter anak. Demikian pula mengapa kurikulum 2013 pengembangan sikap untuk SD menjadi kepedulian utama.

Kebiasaan baik perlu upaya transformasi nilai secara terus menerus sehingga menjadi budaya suatu masyarakat. Prosesnya dari kebiasaan akan menjadi tradisi dan selanjutnya menjadi budaya, dan inilah modal paling mahal dalam membangun peradaban bangsamenjadikan nilai-nilai kemuliaan dan keutamaan (sopan santun, diisiplin, jujur, bersih, toleran, produktif, kreatif) menjadi kebiasaan. Tidak ada yang sulit jika sudah menjadi kebiasaan.

Pembentukan karakter membutuhkan waktu, proses berkesinambungan, daya gugah dan sentuh ke kedalaman emosi dengan cara-cara kreatif dan inovatif, serta melibatkan semua pihak (guru, orangtua, dan masyarakat). Jadi ada empat tahap yang harus dioptimalkan, yaitu: 1) keteladanan; 2) mengembangkan pemahaman manfaat baik dan buruk; 3) mengajak secara verbal kepada sebuah pilihan perilaku, dan 4) menerangi atau melapangkan kemudahan bagi terbiasanya perilaku yang harus dipilih.

\section{2) Proses pendidikan karakter di sekolah}

Harus ada perubahan paradigma dalam proses belajar mengajar. Proses belajar mengajar bukan hanya merupakan prakarsa bagi terjadinya transfer pengetahuan dan keterampilan, tetapi juga meliputi transfer nilai-nilai budaya dan norma-norma sosial. Pendidkan adalah proses memanusiakan manusia dan mempersiapkan anak didik menghadapi kehidupan sesuai dengan zaman mereka. Itulah arah kurikulum 2013, yaitu peningkatan kompetensi yang utuh antara pengetahuan, keterampilan, dan sikap.

Peran guru sebagai teladan mesti ditonjolkan. Jika ingin mengajarkan karakter, maka perlu harus menampilkan karakter guru terlebih dahulu. Pengaruh-pengaruh yang paling menonjol pada karakter murid tampaknya adalah kualitas-kualitas pribadi guru yang diwujudkan dan diteladani di depan murid (Lickona, 2004).

Selanjutnya, perlunya meleburkan nilai-nilai moral yang relevan di semua mata pelajaran dan kegiatan ekstrakurikuler, ko-kurikuler, dan ekstrakurikuler. Nilai compassion, fairness, sportivitas, dan integritas bisa dileburkan dalam pelajaran olahraga. Penilainnya pun tak semata pada pengetahuan anak didik tentang karakter baik, tetapi juga sikap dan perilaku nyata sehari-hari di sekolah maupun di luar sekolah.

\section{3) Penguatan Pendidikan karakter pada kurikulum 2013 melibatkan lingkungan}

Interaksi sosial anak-anak dengan lingkungan sekitar mereka perlu dijadikan sebagai laboratorium etik. Dari pergaulan sehari-hari dengan masyarakat, mereka bisa belajar langsung kesantunan dan kepekaan soaial. Perlu dirancang pula kegiatan-kegiatan menantang tapi 
menyenangkan, seperti kunjungan sosial ke panti jompo, ke lokasi bencana alam, ke pemukiman kumuh, ke pusat-pusat pengembangan teknologi kontemporer, dan lain-lain. Hal tersebut adalah cara-cara belajar visual untuk memberikan pelajaran karakter yang sekaligus dapat membangkitkan rasa kepekaan sosial, dan rasa mencintai sains.

Membangun kultur budaya sekolah yang kondusif dalam membentuk karakter siswa. Budaya sekolah yang sehat perlu dukungan dari kepala sekolah, guru, petugas administrasi, siswa, dan masyarakat sekitar sekolah. Mengkondisikan lingkungan berdasarkan konsep budaya sekolah sehat yang jelas dijaga dan dipupuk.

Sehingga sangat perlu sekolah bekerjasama dengan keluarga siswa, media massa, dan lembaga-lembaga sosial lainnya untuk sama-sama berperan membendung arus karakter negatif dan membangun karakter positif bagi calon generasi bangsa

\section{Hasil Penerapan Kompetensi Abad 21 dan Penguatan Pendidikan Karakter pada Pelatihan Kurikulum 2013 bagi Guru SD}

Penguatan karakter bukan sekadar mengajarkan mana yang benar dan mana yang salah, lebih dari itu, yaitu menanamkan kebiasaan (habituation) tentang hal mana yang baik sehingga peserta pelatihan. Pendidikan karakter menekankan pada habit atau kebiasaan yang terus-menerus dipraktikkan dan dilakukan(Lickona, 2004).

Hasil penerapan kompetensi abad 21 dan PPK setelah pelatihan kurikulum 2013 pada makalah ini akan difokuskan pada hasil pencapaian 4 (empat) standar, yaitu Standar Kompetensi Lulusan (SKL), standar isi, standar proses, dan standar penilaian. dari data potret Rapor Mutu Pendidikan Jenjang SD Provinsi Jawa Tengah Tahun 2017. Alasan mengambil empat standar dalam menganalisis hasil penerapan kompetensi abad 21 dan PPK, karena empat standar tersebut merupakan hasil pemahaman guru SD dalam mengikuti pelatihan kurikulum 2013. Pemahaman kompetensi abad 21 pada proses pembelajaran dibuktikan dengan pencapaian di standar isi, standar proses, dan standar penilaian yang akan berdampak pada kualitas SKL. Menurut Permendikbud nomor 20 Tahun 2016 bahwa Setiap lulusan satuan pendidikan dasar dan menengah memiliki kompetensi pada tiga dimensi yaitu sikap, pengetahuan, dan keterampilan (Permendikbud nomor 20, 2016). Jadi yang akan dilihat pada makalah ini apakah pelatihan kurikulum 2013 berdampak pada perubahan sikap, pengetahuan, ketrampilan siswa jenjang SD provinsi Jawa Tengah, serta pencapaian hasil pada standar isi, standar proses, dan standar penilaian. Berikut Tabel 2. hasil Rapor Mutu PMP jenjang SD tahun 2017 (Dikdasmen, 2018).

Tabel 2. Hasil Raport Mutu PMP SD Tahun 2017

\begin{tabular}{|c|c|c|c|c|c|c|c|}
\hline \multicolumn{8}{|c|}{ KATEGORI CAPAIAN } \\
\hline & Kategori & $\begin{array}{l}\text { Batas } \\
\text { Bawah }\end{array}$ & & $\begin{array}{l}\text { Batas } \\
\text { Atas }\end{array}$ & & & \\
\hline * & Menuju SNP 1 & 0 & & 2,04 & & & \\
\hline$* *$ & Menuju SNP 2 & 2,05 & & 3,7 & & & \\
\hline$* \star *$ & Menuju SNP 3 & 3,71 & & 5,06 & & & \\
\hline$\star * \star *$ & Menuju SNP 4 & 5,07 & & 6,66 & & & \\
\hline$\star \star * \star \star *$ & SNP & 6,67 & & 7 & & & \\
\hline \multicolumn{2}{|c|}{$\begin{array}{l}\text { STANDAR / INDIKATOR / SUB } \\
\text { INDIKATOR }\end{array}$} & \multicolumn{3}{|c|}{ CAPAIAN 2016} & \multicolumn{3}{|c|}{ CAPAIAN 2017} \\
\hline Nomor & Standar / Indikator / Sub & Bobot & Nilai & Kategor & Bobot & Nilai & Kateg \\
\hline
\end{tabular}


SHEs: Conference Series 1 (1) (2018) 523-531

\begin{tabular}{|c|c|c|c|c|c|}
\hline & Indikator & & $\mathrm{i}$ & & ori \\
\hline 1 & $\begin{array}{l}\text { Standar Kompetensi } \\
\text { Lulusan }\end{array}$ & 5,2 & $* \star * * *$ & 5,99 & 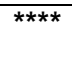 \\
\hline 1.1. & $\begin{array}{l}\text { Lulusan memiliki kompetensi } \\
\text { pada dimensi sikap }\end{array}$ & 6,43 & 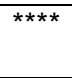 & 6,84 & 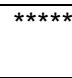 \\
\hline 1.2. & $\begin{array}{l}\text { Lulusan memiliki kompetensi } \\
\text { pada dimensi pengetahuan }\end{array}$ & 3,27 & ** & 3,79 & $* \star * *$ \\
\hline 1.3. & $\begin{array}{l}\text { Lulusan memiliki kompetensi } \\
\text { pada dimensi keterampilan }\end{array}$ & 5,9 & **** & 6,33 & $\star \star \star \star * *$ \\
\hline 2 & Standar Isi & 4,92 & 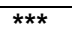 & 5,54 & 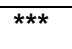 \\
\hline 2.1 . & $\begin{array}{l}\text { Perangkat pembelajaran } \\
\text { sesuai rumusan kompetensi } \\
\text { lulusan }\end{array}$ & 6,58 & 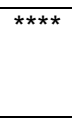 & 5,72 & $\star * * *$ \\
\hline 2.2 . & $\begin{array}{l}\text { Kurikulum Tingkat Satuan } \\
\text { Pendidikan dikembangkan } \\
\text { sesuai prosedur }\end{array}$ & 3,69 & ** & 5,58 & $\star \star *$ \\
\hline 2.3 . & $\begin{array}{l}\text { Sekolah melaksanakan } \\
\text { kurikulum sesuai ketentuan }\end{array}$ & 4,5 & $* * *$ & 5,43 & $* \star * *$ \\
\hline 3 & Standar Proses & 5,19 & 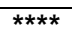 & 6,41 & $\star \star \star \star \star$ \\
\hline 3.1. & $\begin{array}{l}\text { Sekolah merencanakan } \\
\text { proses pembelajaran sesuai } \\
\text { ketentuan }\end{array}$ & 5,53 & $* * * *$ & 6,62 & 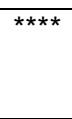 \\
\hline 3.2 . & $\begin{array}{l}\text { Proses pembelajaran } \\
\text { dilaksanakan dengan tepat }\end{array}$ & 5,41 & 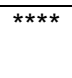 & 6,57 & $\star * * * *$ \\
\hline 3.3. & $\begin{array}{l}\text { Pengawasan dan penilaian } \\
\text { otentik dilakukan dalam proses } \\
\text { pembelajaran }\end{array}$ & & & 6,15 & 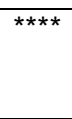 \\
\hline 4 & $\begin{array}{l}\text { Standar Penilaian } \\
\text { Pendidikan }\end{array}$ & 4,44 & $\star \star \star *$ & 5,86 & 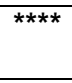 \\
\hline 4.1. & $\begin{array}{l}\text { Aspek penilaian sesuai ranah } \\
\text { kompetensi }\end{array}$ & 4,74 & $\star \star \star *$ & 6,32 & 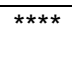 \\
\hline 4.2 . & $\begin{array}{l}\text { Teknik penilaian obyektif dan } \\
\text { akuntabel }\end{array}$ & 4,41 & 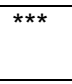 & 5,61 & **** \\
\hline 4.3. & $\begin{array}{l}\text { Penilaian pendidikan } \\
\text { ditindaklanjuti }\end{array}$ & 4,33 & $\star * *$ & 6,3 & 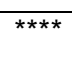 \\
\hline 4.4. & $\begin{array}{l}\text { Instrumen penilaian } \\
\text { menyesuaikan aspek }\end{array}$ & 4,27 & $* \star *$ & 5,45 & $\star \star * \star * *$ \\
\hline 4.5. & $\begin{array}{l}\text { Penilaian dilakukan mengikuti } \\
\text { prosedur }\end{array}$ & 4,46 & $* * *$ & 5,65 & $* * * *$ \\
\hline
\end{tabular}

Pada tabel 2 di atas menunjukkan bahwa pelatihan kurikulum 2013 yang menerapkan kompetensi abad 21 dan PPK berdampak pada peningkatan SKL pada dimensi sikap mengalami kenaikan yaitu tahun 2016 6,43 pada tahun 2017 mengalami kenaikan menjadi 6,84 . Pada dimensi pengetahuan juga mengalami kenaikan tahun 2016 3,27 sedangkan tahun 2017 menjadi 3,79. Dimensi ketrampilan juga mengalami kenaikan dari 5,9 naik menjadi 6,33. Dari pencapaian tersebut dapat dikatakan bahwa pelatihan kurikulum 2013 guru SD dapat meningkatkan pencapaian SKL. Demikian juga pemahaman guru SD terhadap standar isi, standar proses, dan standar penilaian berdampak baik, terbukti ada kenaikan pada pencapaian standar isi tahun 2016 4,92 tahun 2017 naik menjadi 5,54 walaupun masih dalam kategori menuju SNP $3\left(^{* * *}\right)$. Pada standar proses juga mengalami kenaikan tahun 20165,19 pada tahun 2017 menjadi 6,41. Standar penilaian juga mengalami kenaikan tahun 2016 4,44 tahun 2017 menjadi 5,86. Jadi pelatihan kurikulum 2013 dapat meningkatkan pencapaian pada standar kompetensi lulusan, standar isi, standar proses dan standar penilaian. 


\section{SIMPULAN}

1. Peran kurikulum 2013 dalam pembentukan karakter diantaranya adalah: 1) adanya upaya keteladanan guru dan program pembiasaan karakter-karakter positif; 2) Adanya proses pendidikan karakter di sekolah, yaitu melalui peningkatan kompetensi yang utuh antara pengetahuan, keterampilan, dan sikap.

2. Hasil pelatihan kurikulum 2013 berdampak pada peningkatan pencapaian Standar Nasional Pendidikan pada SKL, standar isi, standar proses, dan standar penilaian.

\section{DAFTAR PUSTAKA}

Dikdasmen. (2018). http://pmp.dikdasmen.kemdikbud.go.id/raporNG/index.php (Februari 2018).

Haryati, T. a. (2017). Implementasi Model Pengelolaan Kurikulum Pendidikan Karakter Integratif di Universitas PGRI Semarang. Diambil kembali dari eprints upgris: http://eprints.upgris.ac.id/id/eprint/217

Lickona, T. (2004). Character Matters. NY: Touchstone Book.

Peraturan Presiden nomor 87 Tahun 2017. (t.thn.). Penguatan Pendidikan Karakter. Permendikbud nomor 20. (2016). Standar Kompetensi Lulusan. Dalam Kemdikbud.

Undang-Undang Sistem Pendidikan Nasional nomor 20 Tahun 2003. (t.thn.). 